\title{
Effects of fluctuating glucose concentrations on oxidative metabolism of glucose in cultured neurons and astroglia
}

\author{
Shinichi Takahashi ${ }^{{ }^{*}}$, Takato Abe $^{2}$, Yoshikane Izawa ${ }^{1}$, Norihiro Suzuki ${ }^{1}$ \\ ${ }^{1}$ Department of Neurology, School of Medicine, Keio University, Tokyo, Japan; ${ }^{*}$ Corresponding Author: takashin@tka.att.ne.jp \\ ${ }^{2}$ Department of Internal Medicine, Tokyo Dental College, Ichikawa General Hospital, Chiba, Japan
}

Received 28 November 2011; revised 31 December 2011; accepted 13 January 2012

\begin{abstract}
The objective of the present study was to evaluate the effects of hyperglycemia on glucose metabolism of brain cells. Not only a sustained hyperglycemic state, but also a fluctuating plasma glucose concentration has been implicated in the pathogenesis of diabetic angiopathy. Acutely increasing plasma glucose levels have not been reported to alter glucose utilization of the brain as a whole. In the present study, we examined the effects of chronic ( 3 weeks) or short-term (24-hour) exposure to a high glucose concentration on the oxidative metabolism of neurons and astroglia. Cells were prepared from Sprague-Dawley rats and cultured in the presence of a high (22 $\mathrm{mM}$ ) or low (5 $\mathrm{mM}$ ) concentration of glucose. The high or low glucose media did not alter either the rates of $\left[{ }^{14} \mathrm{C}\right]$ deoxyglucose phosphorylation (an indicator of total glucose utilization) or $\left[{ }^{14} \mathrm{C}\right]$ lactate and $\left[{ }^{14} \mathrm{C}\right]$ pyruvate oxidation (indicators of oxidative glucose metabolism) in neurons. In contrast, chronic or short-term exposure to a high glucose concentration resulted in significant decreases in oxidation of $\left[{ }^{14} \mathrm{C}\right]$ acetate, an astrocyte-specific reporter molecule, or $\left[{ }^{14} \mathrm{C}\right]$ lactate and $\left[{ }^{14} \mathrm{C}\right]$ pyruvate oxidation in the astroglia. Thus, either chronic or short-term increases in the glucose concentration suppressed oxidative metabolism only in astroglia, indicating neuro-protective roles against hyperglycemic brain cell injury in diabetes mellitus. These different responses of neurons and astroglia may also shed new light on brain energy metabolism in diabetic patients with either chronic high or fluctuating plasma glucose concentrations.
\end{abstract}

Keywords: Astrocyte; Diabetic Encephalopathy;
Hyperglycemia; $\left[{ }^{14} \mathrm{C}\right]$ Acetate; $\left[{ }^{14} \mathrm{C}\right]$ Deoxyglucose; $\left[{ }^{14} \mathrm{C}\right]$ Lactate; $\left[{ }^{14} \mathrm{C}\right]$ Pyruvate

\section{INTRODUCTION}

Diabetes mellitus is a major risk factor of cardiovascular diseases [1]. Moreover, several population-based studies have revealed that diabetic patients suffer from dementia more frequently than normal age-matched people [2]. Interestingly, diabetes mellitus causes not only vascular dementia, but also non-vascular type of dementia (i.e., Alzheimer disease). The mechanism by which diabetes mellitus causes dementia independent of vascular factors remains to be solved. Recent findings suggest that persistent hyperglycemia per se induces the overproduction of reactive oxygen species (ROSs), which play a unifying role in several pathomechanisms of both peripheral and central nervous system impairment in diabetic patients $[3,4]$.

Not only a sustained hyperglycemic state, but also acute hyperglycemia or a fluctuating plasma glucose concentration has been implicated in the pathogenesis of diabetic angiopathy $[5,6]$ and the derangement of brain energy metabolism [7] as well as cognitive function (i.e., diabetic encephalopathy) [8-11]. Acute hyperglycemia is not thought to alter the cerebral metabolic rate of glucose $\left(\mathrm{CMR}_{\mathrm{glc}}\right)[12,13]$. However, whether chronic hyperglycemia enhances or suppresses the $\mathrm{CMR}_{\mathrm{glc}}$ remains controversial $[12,14]$, and the effect of a fluctuating plasma glucose concentration on the $\mathrm{CMR}_{\mathrm{glc}}$ has not been examined extensively. Moreover, the effect of hyperglycemia on the cerebral metabolic rate of oxygen $\left(\mathrm{CMRO}_{2}\right)$ remains to be examined [15-17].

Astrocytes are thought to be more dependent on glycolytic, rather than oxidative, glucose metabolism for energy production. Recent findings, however, have revealed that oxidative metabolism in astrocytes might be comparable to that in neurons in vitro and in vivo [18]. Recently, we reported that oxidative metabolism in as- 
trocytes depended on the environmental glucose concentration in vitro [19]. Therefore, the role of astrocytic oxidative glucose metabolism in the in terms of ROSs generation under a hyperglycemic state should be determined. In the present study, we examined the effects of chronic or short-term exposure to a high glucose concentration on total (both glycolytic and oxidative) and mitochondrial (oxidative) metabolism of glucose in neurons and astroglia in vitro, as assessed by monitoring ${ }^{14} \mathrm{C}$ labeled substrates.

\section{MATERIALS AND NETHODS}

\subsection{Animals}

Timed-pregnant Sprague-Dawley rats were purchased from Japan SLC, Inc. (Hamamatsu, Japan). All animal procedures were performed in accordance with The Animal Experimentation Guidelines of Keio University School of Medicine and were approved by the Laboratory Animal Care and Use Committee of Keio University.

\subsection{Chemicals}

Chemicals and materials were obtained from the following sources: 2-deoxy-D-[1- $\left.{ }^{14} \mathrm{C}\right]$ glucose $\left(\left[{ }^{14} \mathrm{C}\right]\right.$ deoxyglucose; specific activity, $2.0 \mathrm{GBq} / \mathrm{mmol})$, L-[U- $\left.{ }^{14} \mathrm{C}\right] \mathrm{lac}-$ tate $\left(\left[{ }^{14} \mathrm{C}\right]\right.$ lactate; specific activity, $\left.4.84 \mathrm{GBq} / \mathrm{mmol}\right)$, $\left[1-{ }^{14} \mathrm{C}\right]$ pyruvate $\left(\left[{ }^{14} \mathrm{C}\right]\right.$ pyruvate; specific activity, 0.67 $\mathrm{GBq} / \mathrm{mmol}),\left[1{ }^{14} \mathrm{C}\right]$ acetate $\left(\left[{ }^{14} \mathrm{C}\right]\right.$ acetate; specific activity, $2.09 \mathrm{GBq} / \mathrm{mmol}$ ), Insta-Fluor Plus and hyamine hydroxide 10-X were obtained from Perkin-Elmer Life Sciences (Boston, MA, USA); Dulbecco's modified Eagle medium with or without glucose, penicillin, and streptomycin were obtained from Life Technologies (Grand Island, NY, USA); defined fetal bovine serum was obtained from HyClone Laboratories (Logan, UT, USA); trypsin-EDTA was obtained from Boehringer Mannheim (Indianapolis, IN, USA); and all other chemicals were obtained from Sigma (St Louis, MO, USA).

\subsection{Preparation of Cells}

Primary astroglial cultures were prepared from the cerebral cortex of rat pups 24 to 48 hours after birth [20]. The dissociated cells from the frontoparietal cortices $(2.5$ $\times 10^{5}$ cells $\left./ \mathrm{mL}\right)$ were plated $(15 \mathrm{~mL} /$ flask $)$ in uncoated $75-\mathrm{cm}^{2}$ culture flasks (Sumitomo Bakelite, Tokyo, Japan) and cultured in a high-glucose medium (final concentration, $22 \mathrm{mM}$ of glucose) comprised of Dulbecco's modified Eagle medium with $10 \%(\mathrm{v} / \mathrm{v})$ fetal bovine serum, penicillin $(100 \mathrm{U} / \mathrm{mL})$, and streptomycin $(100 \mu \mathrm{g} / \mathrm{mL})$ at $37^{\circ} \mathrm{C}$ in humidified air containing $7 \% \mathrm{CO}_{2}$ (day 0 ). The culture medium was changed every two days until the cultures reached confluence (usually on day 9 to 11 ). On day 10 , the adherent cells were treated with trypsinEDTA solution, suspended in fresh high-glucose medium, and placed in uncoated 24-well culture plates (Sumitomo Bakelite, Tokyo, Japan) or in $25-\mathrm{cm}^{2}$ culture flasks (Nalge Nunc., Rochester, NY, USA). From the day after subculturing, some of the cells were cultured in a lowglucose medium (final concentration, $5 \mathrm{mM}$ of glucose) comprised of Dulbecco's modified Eagle medium without glucose but supplemented with D-glucose, fetal bovine serum, penicillin, and streptomycin. The culture medium was changed twice a week, and the cells were used once they reached confluence (days 22 to 24).

The primary neuron culture was prepared from the striata of fetal rats on embryonic day 16, as described previously [20]. The mechanically dissociated cells were placed $(0.4 \mathrm{~mL} /$ well $)$ in 24 -well culture plates or $25-\mathrm{cm}^{2}$ culture flasks coated with poly-L-lysine $(5 \mu \mathrm{g} / \mathrm{mL})$. Cells were cultured in high-glucose (final concentration, 22 $\mathrm{mM}$ ) Dulbecco's modified Eagle medium at $37^{\circ} \mathrm{C}$ in humidified air containing $7 \% \mathrm{CO}_{2}$. Cytosine arabinoside $(10 \mu \mathrm{mol} / \mathrm{L})$ was added 72 hours later to induce the mitotic arrest of the astroglia. Assays were performed using cultures that were 8 to 10 days old. The nutrient medium remained untouched until the experiments were initiated.

\subsection{Assay for 2-Deoxy-D-[1- $\left.{ }^{14} \mathrm{C}\right]$ Glucose Phosphorylation}

The rates of glucose phosphorylation in neurons and astroglia were evaluated using the $\left[{ }^{14} \mathrm{C}\right]$ deoxyglucose method [20,21], which is an indicator of total glucose utilization. The culture medium was replaced by $0.4 \mathrm{~mL}$ of Dulbecco's balanced salt solution (DBSS) containing $110 \mathrm{mM} \mathrm{NaCl}, 5.4 \mathrm{mM} \mathrm{KCl}, 1.8 \mathrm{mM} \mathrm{CaCl}_{2}, 0.8 \mathrm{mM}$ $\mathrm{MgSO}_{4}, 0.9 \mathrm{mM} \mathrm{NaH}_{2} \mathrm{PO}_{4}$, and $44 \mathrm{mM} \mathrm{NaHCO}$ with 2 $\mathrm{mM}$ glucose and $10 \mathrm{~mL}$ of $\left[{ }^{14} \mathrm{C}\right]$ deoxyglucose $(3.7$ $\mathrm{MBq} / \mathrm{mL})$; incubation was continued for 30 minutes at $37^{\circ} \mathrm{C}, 7 \% \mathrm{CO}_{2}$. At the end of the incubation period, the DBSS was replaced by a fresh reaction mixture lacking $\left[{ }^{14} \mathrm{C}\right]$ deoxyglucose; incubation was continued at $37^{\circ} \mathrm{C}$, $7 \% \mathrm{CO}_{2}$ for 5 minutes to allow the efflux of residual $\left[{ }^{14} \mathrm{C}\right]$ deoxyglucose from the cells. The cell carpets were washed quickly three times with ice-cold PBS and digested in $0.2 \mathrm{~mL}$ of $0.1 \mathrm{mM} \mathrm{NaOH}$ at room temperature. The cell digests were then assayed for protein content using the bicinchoninic acid method [22], and the ${ }^{14} \mathrm{C}$ count was measured using a liquid scintillation counter (Tri-Carb 3100TR; Perkin-Elmer Life Sciences, Boston, MA, USA).

\subsection{Measurement of the Rate of L-[U- $\left.-{ }^{14} \mathrm{C}\right]$ Lactate, $\left[1-{ }^{14} \mathrm{C}\right]$ Pyruvate, and $\left[1-{ }^{14} \mathrm{C}\right]$ Acetate Oxidation to ${ }^{14} \mathrm{CO}_{2}$}

The rate of $\left[{ }^{14} \mathrm{C}\right]$ lactate, $\left[{ }^{14} \mathrm{C}\right]$ pyruvate, and $\left[{ }^{14} \mathrm{C}\right]$ ace- 
tate oxidation to ${ }^{14} \mathrm{CO}_{2}$ was measured using a modification of a previously described method [19], which is an indicator of oxidative glucose metabolism. After cells cultured in $25-\mathrm{cm}^{2}$ culture flasks were washed twice with PBS, $2.5 \mathrm{~mL}$ of DBSS containing $2 \mathrm{mM}$ of lactate and $2.5 \mu \mathrm{L}$ of $\left[{ }^{14} \mathrm{C}\right]$ lactate (original concentration: $3.7 \mathrm{MBq} /$ $\mathrm{mL}), 2 \mathrm{mM}$ of pyruvate and $2.5 \mu \mathrm{L}$ of $\left[{ }^{14} \mathrm{C}\right]$ pyruvate (original concentration: $18.5 \mathrm{MBq} / \mathrm{mL}$ ), or $0.2 \mathrm{mM}$ of acetate and $0.25 \mu \mathrm{L}$ of $\left[{ }^{14} \mathrm{C}\right]$ acetate (original concentration: $37 \mathrm{MBq} / \mathrm{mL}$ ) was added to the flasks. The culture flasks were then capped with rubber stoppers containing a center well and incubated at $37^{\circ} \mathrm{C}$ for 60 minutes. The ${ }^{14} \mathrm{CO}_{2}$ produced was trapped by a cotton ball placed in the center well containing $100 \mu \mathrm{L}$ of hyamine hydroxide $10-\mathrm{X}$. The reactions were terminated by the injection of $250 \mu \mathrm{L}$ of $60 \%$ perchloric acid through the rubber stopper, and the flasks were kept at $4^{\circ} \mathrm{C}$ overnight to trap the ${ }^{14} \mathrm{CO}_{2}$. The center wells were transferred to $20-\mathrm{mL}$ glass scintillation counter vials, and $500 \mu \mathrm{L}$ of ethanol and 10 $\mathrm{mL}$ of Insta-Fluor Plus were added. The ${ }^{14} \mathrm{C}$ contents of the vials were then evaluated using a liquid scintillation counter. [23] reported that substantial ${ }^{14} \mathrm{C}$ counts were obtained from a flask without cells. Therefore, the ${ }^{14} \mathrm{C}$ counts obtained from a flask without cells in which the reaction had been stopped at 60 mins were regarded as the background values and were subtracted in our studies. The cell carpets left in the incubation flasks after the removal of the reaction mixtures were then digested with $5 \mathrm{~mL}$ of $0.1 \mathrm{M} \mathrm{NaOH}$, and their protein contents were determined.

\subsection{Statistical Analyses}

Statistical comparisons among the values obtained for each group were carried out using grouped $t$-tests. A $P$-value of $<0.05$ was considered statistically significant. For each experiment, at least three sets of assays were performed on different batches of cell preparations, and a set of representative data (mean $\pm \mathrm{SD}$ ) was presented in each figure or table.

\section{RESULTS}

\subsection{Effects of a High Glucose Culture Medium on $\left[{ }^{14} \mathrm{C}\right]$ Deoxyglucose Phosphorylation and $\left[{ }^{14} \mathrm{C}\right]$ Lactate or [14C]Pyruvate Oxidation to ${ }^{14} \mathrm{CO}_{2}$ in Neurons}

As reported previously [19], reducing the glucose concentration of a culture medium to $2 \mathrm{mM}$ elicits an increase in the oxidative glucose metabolism of cultured rat astroglia. However, the effect of different concentrations of glucose in culture media on total glucose utilizetion or glucose oxidation in neurons remains to be evalu- ated. Therefore, we first compared the rates of $\left[{ }^{14} \mathrm{C}\right] \mathrm{de}-$ oxyglucose phosphorylation (total glucose utilization) in neurons cultured in the presence of $5 \mathrm{mM}$ of glucose with those cultured in the presence of $22 \mathrm{mM}$ of glucose. As shown in Table 1, no difference was found in the rates of $\left[{ }^{14} \mathrm{C}\right]$ deoxyglucose phosphorylation in astroglia cultured under the two different glucose conditions, confirming our previous results [19]. No difference in the rates of $\left[{ }^{14} \mathrm{C}\right]$ deoxyglucose phosphorylation was noted in the neuronal cultures, either. Under both conditions, the rates of $\left[{ }^{14} \mathrm{C}\right]$ deoxyglucose phosphorylation were higher in the astroglia than in the neurons.

Secondly, we examined the oxidation of $\left[{ }^{14} \mathrm{C}\right]$ lactate to ${ }^{14} \mathrm{CO}_{2}$ (oxidative glucose metabolism) in neurons and astroglia cultured in media with high $(22 \mathrm{mM})$ or low $(5$ $\mathrm{mM}$ ) glucose concentrations. As reported previously [19], $\left[{ }^{14} \mathrm{C}\right]$ lactate oxidation was suppressed in the astroglia that had been cultured in the presence of $22 \mathrm{mM}$ of glucose, compared with those that had been cultured in the presence of $5 \mathrm{mM}$ of glucose (Table 2). The rates of $\left[{ }^{14} \mathrm{C}\right]$ lactate oxidation in neurons, however, showed no statistically significant difference after 7 days of cultivation in the presence of $5 \mathrm{mM}$ or $22 \mathrm{mM}$ of glucose (Table 2).

To verify that the increases in $\left[{ }^{14} \mathrm{C}\right]$ lactate oxidation to ${ }^{14} \mathrm{CO}_{2}$ in astroglia were not attributable to the cellular uptake of lactate, the time course of $\left[{ }^{14} \mathrm{C}\right]$ lactate accumulation in the cells was also observed. Figure 1 shows that ${ }^{14} \mathrm{C}$ accumulated in a linear manner during the initial 10 - 30 minutes and then gradually leveled off thereafter.

Table 1. $\left[{ }^{14} \mathrm{C}\right]$ Deoxyglucose phosphorylation (pmol deoxyglucose $/ \mu \mathrm{g}$ protein/60 $\mathrm{min}$ ) by astroglia and neurons grown in high-(22 mM) or low-(5 mM) glucose medium.

\begin{tabular}{ccc}
\hline & High-glucose medium & Low-glucose medium \\
\hline Astroglia & $2.6 \pm 0.7^{\mathrm{a}}(\mathrm{n}=8)$ & $2.4 \pm 0.9(\mathrm{n}=8)$ \\
Neurons & $1.0 \pm 0.02^{\mathrm{a}, \mathrm{b}}(\mathrm{n}=4)$ & $1.0 \pm 0.2^{\mathrm{b}}(\mathrm{n}=4)$ \\
\hline
\end{tabular}

Values are the mean $\pm \mathrm{SD}$ of number (n) of experiments carried out under

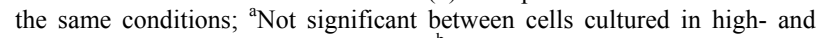
low-glucose medium (grouped $t$-test); ${ }^{b} P<0.01$ vs. astroglia cultured in high- or low-glucose medium (grouped $t$-test).

Table 2. $\left[{ }^{14} \mathrm{C}\right]$ Lactate oxidation to ${ }^{14} \mathrm{CO}_{2}$ (pmol lactate/ $\mu$ g protein/60 $\mathrm{min}$ ) by astroglia and neurons grown in high- $(22 \mathrm{mM})$ or low-(5 mM) glucose medium.

\begin{tabular}{ccc}
\hline & High-glucose medium & Low-glucose medium \\
\hline Astroglia & $2.3 \pm 0.5^{\mathrm{a}}(\mathrm{n}=4)$ & $4.8 \pm 0.4(\mathrm{n}=4)$ \\
Neurons & $10.7 \pm 1.6^{\mathrm{b}, \mathrm{c}}(\mathrm{n}=4)$ & $12.3 \pm 1.5^{\mathrm{c}}(\mathrm{n}=4)$ \\
\hline
\end{tabular}

Values are the mean $\pm \mathrm{SD}$ of number $(\mathrm{n})$ of experiments carried out under the same conditions. ${ }^{\mathrm{a}} \mathrm{P}<0.01$ vs. astroglia cultured in low-glucose medium (grouped $t$-test). b Not significant vs. neurons cultured in low-glucose medium (grouped $t$-test). ${ }^{\mathrm{c}} P<0.01$ vs. astroglia cultured in high- or low-glucose medium (grouped $t$-test). 


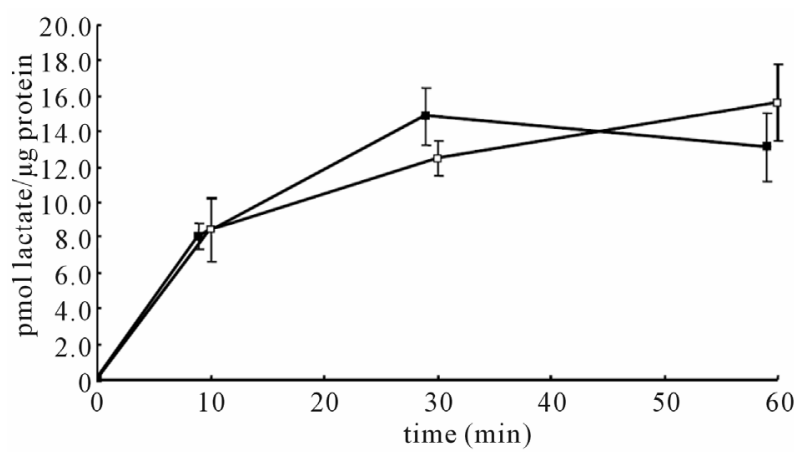

Figure 1. Time courses of $\left[{ }^{14} \mathrm{C}\right]$ lactate accumulation in astroglia cultured in the presence of high $(22 \mathrm{mM})$ or low $(5 \mathrm{mM})$ glucose concentrations. Values are the mean \pm SD of quadruplicate wells. Closed squares indicate cells cultured in highglucose conditions, and open squares indicate those cultured in low-glucose conditions.

No difference was observed in the uptake process between astroglia cultured in the presence of $5 \mathrm{mM}$ or 22 $\mathrm{mM}$ of glucose, indicating that the decreased production of ${ }^{14} \mathrm{CO}_{2}$ from $\left[{ }^{14} \mathrm{C}\right]$ lactate did not reflect an alteration of uptake by monocarboxylate transporters (MCTs), but the oxidation of $\left[{ }^{14} \mathrm{C}\right]$ lactate.

Finally, we examined the oxidation of $\left[{ }^{14} \mathrm{C}\right]$ pyruvate to ${ }^{14} \mathrm{CO}_{2}$ (an indicator of oxidative glucose metabolism, especially pyruvate dehydrogenase; $\mathrm{PDH}$ ) in neurons and astroglia cultured in media with high $(22 \mathrm{mM})$ or low (5 $\mathrm{mM})$ glucose concentrations. Similar to the changes in lactate oxidation, $\left[{ }^{14} \mathrm{C}\right]$ pyruvate oxidation was markedly suppressed in the astroglia that had been cultured in the presence of $22 \mathrm{mM}$ of glucose, but not in neurons (Table $3)$.

\subsection{Acute Effect of Changing Glucose Concentrations on $\left.{ }^{14} \mathrm{C}\right]$ Lactate Oxidation and $\left[{ }^{14} \mathrm{C}\right]$ Deoxyglucose Phosphorylation in Astroglia}

Next, we evaluated the effects on oxidative glucose metabolism of exposing astroglia to media containing high $(22 \mathrm{mM})$ or low $(5 \mathrm{mM})$ glucose concentrations for 24 hours. Twenty-four-hour exposure to a high glucose medium after cultivation in a low-glucose medium resulted in a significant decrease $(p<0.01$, grouped $t$-test) in $\left[{ }^{14} \mathrm{C}\right]$ lactate oxidation in astroglia $(2.9 \pm 0.5$ pmol lactate $/ \mu \mathrm{g}$ protein $/ 60 \mathrm{~min}$, mean $\pm \mathrm{SD}, \mathrm{n}=4$ ), compared with that in cells cultured in the presence of a low glucose concentration $(4.8 \pm 0.4, \mathrm{n}=4)$ (Figure 2). In contrast, 24-hour exposure to a low glucose concentration after cultivation in a high-glucose medium did not affect $\left[{ }^{14} \mathrm{C}\right]$ lactate oxidation in the astroglia (Figure 2).

Despite the fact that fluctuating glucose concentrations altered the rates of $\left[{ }^{14} \mathrm{C}\right]$ lactate oxidation, the rates of $\left[{ }^{14} \mathrm{C}\right]$ deoxyglucose phosphorylation in the astroglia re-
Table 3. $\left[{ }^{14} \mathrm{C}\right]$ Pyruvate oxidation to ${ }^{14} \mathrm{CO}_{2}$ (pmol pyruvate/ $\mu \mathrm{g}$ protein/60 $\mathrm{min})$ by astroglia and neurons grown in high- $(22$ $\mathrm{mM})$ or low- $(5 \mathrm{mM})$ glucose medium.

\begin{tabular}{ccc}
\hline & High-glucose medium & Low-glucose medium \\
\hline Astroglia & $21.8 \pm 3.9^{\mathrm{a}}(\mathrm{n}=4)$ & $34.9 \pm 3.6(\mathrm{n}=4)$ \\
Neurons & $52.0 \pm 4.2^{\mathrm{b}, \mathrm{c}}(\mathrm{n}=4)$ & $54.5 \pm 1.7^{\mathrm{c}}(\mathrm{n}=4)$ \\
\hline
\end{tabular}

Values are the mean \pm SD of number $(n)$ of experiments carried out under the same conditions. ${ }^{a} P<0.01$ vs. astroglia cultured in low-glucose medium (grouped $t$-test). ${ }^{b}$ Not significant vs. neurons cultured in low-glucose medium (grouped $t$-test). ${ }^{\mathrm{c}} P<0.01$ vs. astroglia cultured in high- or low-glucose medium (grouped $t$-test).

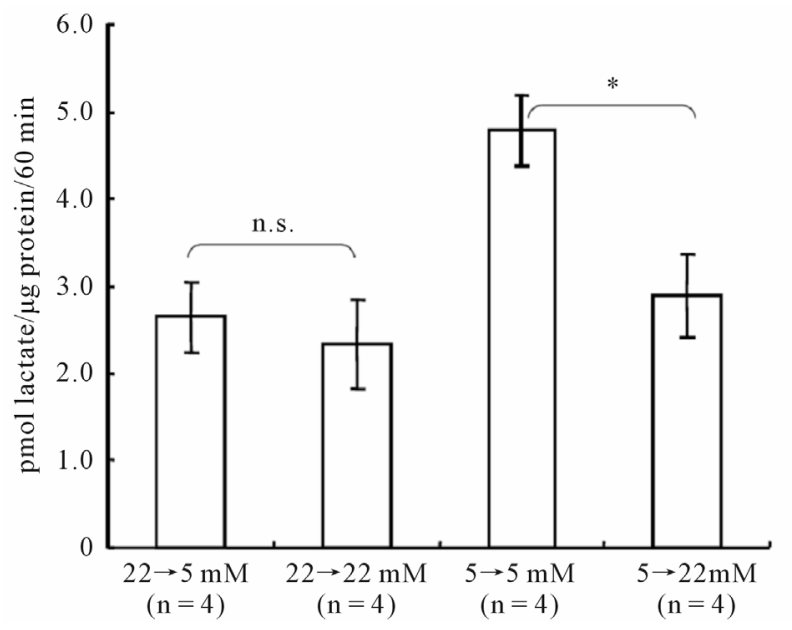

Figure 2. Acute effect of changing glucose concentrations on $\left[{ }^{14} \mathrm{C}\right]$ lactate oxidation in astroglia. Cells were cultured in the presence of the glucose concentration indicated below each column; 24 hours prior to the assay, the glucose concentration was changed as indicated. The column heights and error bars represent the mean and $\mathrm{SD}(\mathrm{n}=4) .{ }^{*} P<0.01$ vs. corresponding astroglia cultured in $5 \mathrm{mM}$ of glucose (grouped $t$-test). n.s.; not significant between astroglia exposed to $5 \mathrm{mM}$ of glucose and corresponding astroglia cultured in the presence of $22 \mathrm{mM}$ of glucose (grouped $t$-test).

mained totally unchanged (Figure 3).

\subsection{Oxidation of $\left[{ }^{14} \mathrm{C}\right] \mathrm{Acc}$ tate in Astroglia as a Result of Chronic and Acute Fluctuations in Glucose Concentrations}

Acetate is known to be taken up by specific MCTs expressed on astrocytes, but not on neurons $[23,24]$. In astroglia, acetate is converted to acetyl-CoA by acetateCoA ligase, then, it enters the tricarboxylic acid (TCA) cycle and produces $\mathrm{CO}_{2}$. Figure 4 shows that the rates of $\left[{ }^{14} \mathrm{C}\right]$ acetate oxidation, as measured by ${ }^{14} \mathrm{CO}_{2}$ production, were markedly higher in astroglia than in neurons. In fact, $\left[{ }^{14} \mathrm{C}\right]$ acetate oxidation in neurons cultured in either a high- or low-glucose medium was negligible (Figure 4, right). In astroglia, however, cultivation in a high-glucose medium elicited a statistically significant $(P<0.01)$ 


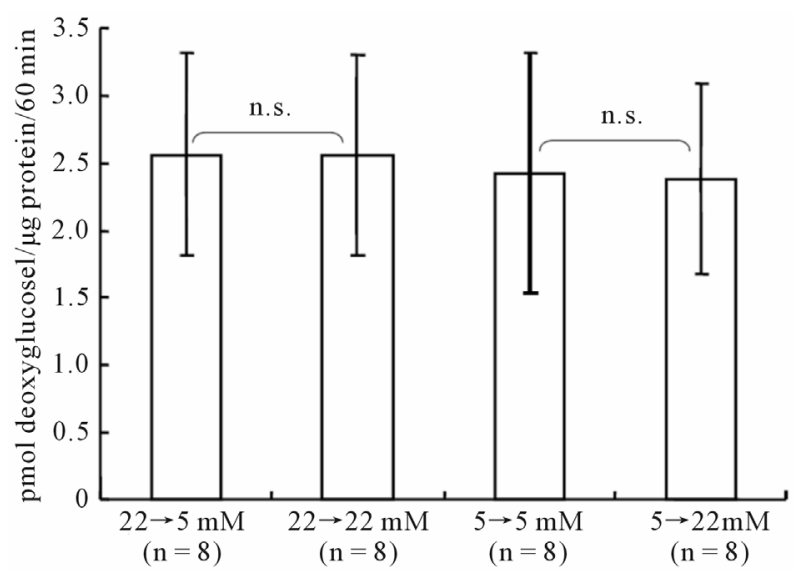

Figure 3. Acute effect of changing glucose concentrations on $\left[{ }^{14} \mathrm{C}\right]$ deoxyglucose phosphorylation in astroglia. Cells were cultured in the presence of the glucose concentration indicated below each column; 24 hours prior to the assay, the glucose concentration was changed as indicated. The column heights and error bars represent the mean and SD of $\left[{ }^{14} \mathrm{C}\right]$ deoxyglucose phosphorylation $(\mathrm{n}=8)$. n.s.; not significant between astroglia exposed to $22 \mathrm{mM}$ or $5 \mathrm{mM}$ of glucose and corresponding astroglia (grouped $t$-test).

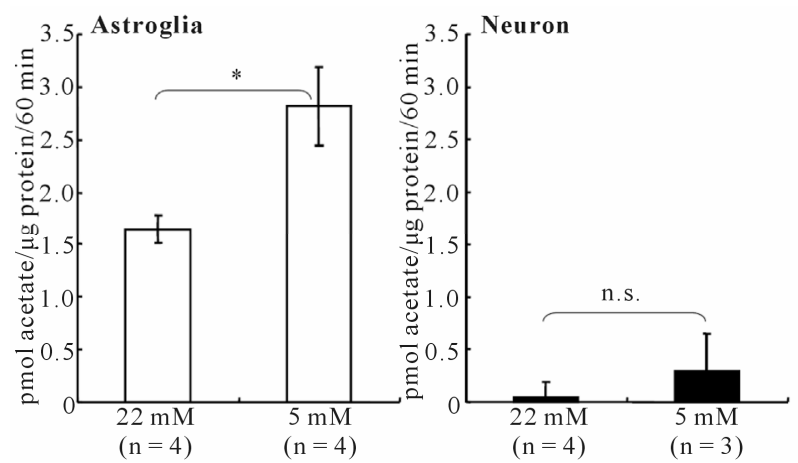

Figure 4. Rates of $\left[{ }^{14} \mathrm{C}\right]$ acetate oxidation in astroglia (left) and neurons (right) cultured in the presence of high $(22 \mathrm{mM})$ or low $(5 \mathrm{mM})$ glucose concentrations. $\left[{ }^{14} \mathrm{C}\right]$ acetate oxidation was much higher in astroglia than in neurons. A low-glucose condition caused a significant increase in the rate of $\left[{ }^{14} \mathrm{C}\right]$ acetate oxidation only in astroglia. ${ }^{*} P<0.01$ between astroglia cultured in the presence of $22 \mathrm{mM}$ or $5 \mathrm{mM}$ of glucose (grouped $t$-test). n.s.; not significant between neurons cultured in the presence of $22 \mathrm{mM}$ or $5 \mathrm{mM}$ of glucose (grouped $t$-test).

decrease in the rate of $\left[{ }^{14} \mathrm{C}\right]$ acetate oxidation, compared with astroglia cultured in a low-glucose medium (Figure 4, left).

The initial rates of uptake of $\left[{ }^{14} \mathrm{C}\right]$ acetate by astroglia cultured in the presence of 5 or $22 \mathrm{mM}$ of glucose did not differ (Figure 5), indicating that transport processes into astroglial cells via MCTs were not responsible for the difference.

Finally, the effect of an acute exposure to changing glucose concentrations on $\left[{ }^{14} \mathrm{C}\right]$ acetate oxidation was evaluated in astroglia. As shown in Figure 6, 24-hour

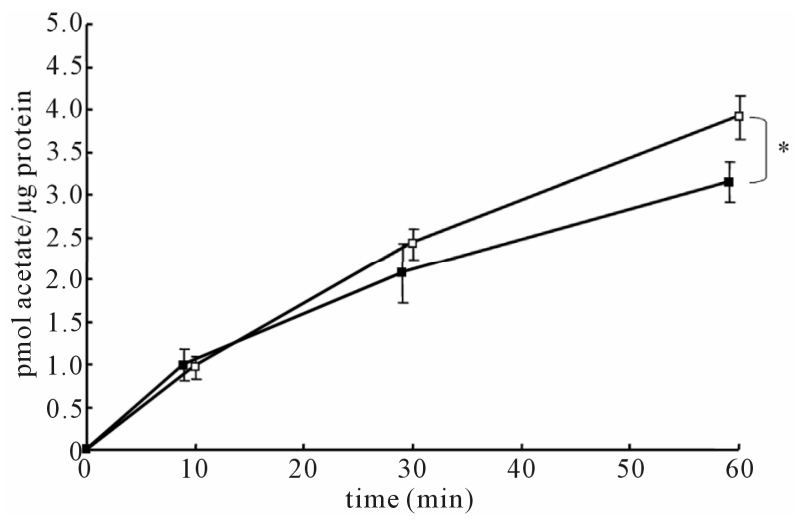

Figure 5. Time courses of $\left[{ }^{14} \mathrm{C}\right]$ acetate accumulation in astroglia cultured in the presence of high $(22 \mathrm{mM})$ or low $(5 \mathrm{mM})$ glucose concentrations. Values are the mean \pm SD of quadruplicate wells. Closed squares indicate cells cultured in highglucose conditions, and open squares indicate those cultured in low-glucose conditions. $* P<0.01$ between astroglia cultured in the presence of $22 \mathrm{mM}$ or $5 \mathrm{mM}$ of glucose (grouped $t$-test) at 60 minutes.

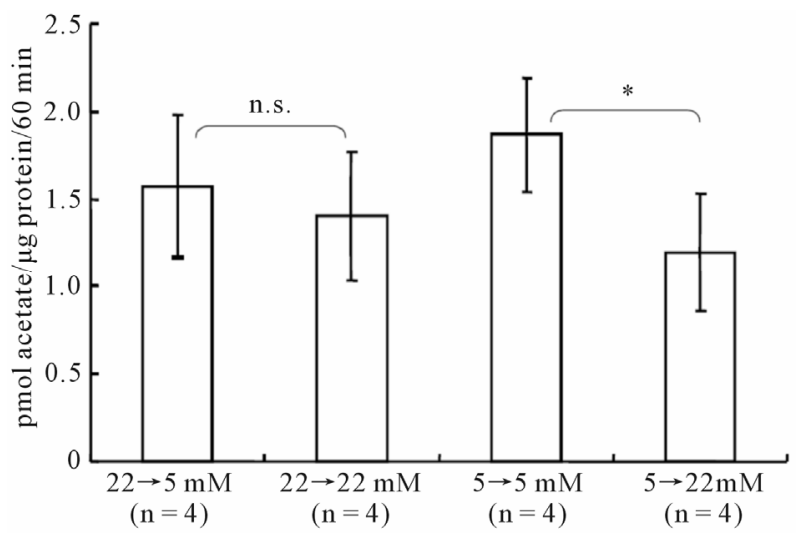

Figure 6. Acute effect of changing glucose concentrations on $\left[{ }^{14} \mathrm{C}\right]$ acetate oxidation in astroglia. Cells were cultured in the presence of the glucose concentration indicated below each column; 24 hours prior to the assay, the glucose concentration was changed as indicated. The column heights and error bars represent the mean and SD of $\left[{ }^{14} \mathrm{C}\right]$ acetate oxidation $(n=4)$. n.s.; not significant between astroglia exposed to $22 \mathrm{mM}$ or 5 $\mathrm{mM}$ of glucose and corresponding astroglia (grouped $t$-test).

exposure to a high glucose concentration suppressed the rates of $\left[{ }^{14} \mathrm{C}\right]$ acetate oxidation in astroglia that had been cultured in a low-glucose medium. In contrast, acute exposure to a low glucose concentration did not elicit a significant alteration in $\left[{ }^{14} \mathrm{C}\right]$ acetate oxidation, similar to the results observed for $\left[{ }^{14} \mathrm{C}\right]$ lactate oxidation.

\section{DISCUSSION}

Normal brain function depends on the complete oxidation of glucose $[25,26]$. In fact, glucose is the sole energy substrate of the brain under normal physiological conditions. Under resting condition, the ratio between $\mathrm{CMRO}_{2}$ / 
$\mathrm{CMR}_{\mathrm{glc}}$ is close to 6.0 [25], which is the theoretical value for the complete oxidation of glucose even though the ratio may temporarily decrease to 5.0 during functional activation [27]. Although the brain as a whole metabolizes glucose oxidatively, the differences in glucose metabolism in neurons and astroglia remain uncertain [28-30].

Glucose in plasma is transported into the brain by facilitated diffusion through a glucose transporter, designnated Glut1, on the endothelium. The glucose concentration of the extracellular fluid in rat brain is approximately 0.5 to $3.3 \mathrm{mM}[31,32]$, and this concentration can increase as the plasma glucose concentration rises both acutely [32] and chronically [33]. Acute hyperglycemia does not alter the $\mathrm{CMR}_{\mathrm{glc}}[12,13]$. However, whether chronic hyperglycemia decreases [12] or increases the $\mathrm{CMR}_{\text {glc }}$ [14] remains controversial. Although fluctuating plasma glucose concentrations have been implicated in the pathogenesis of diabetic angiopathy $[5,6]$, the effects on brain energy metabolism have not been examined extensively.

Diabetes mellitus has been reported to be a risk factor for dementia [2], not only as a result of cerebrovascular events, but also because of direct damage to neural cells (i.e., diabetic encephalopathy). The exact mechanisms by which neuronal injury occurs, however, remain uncertain. $[3,4]$ postulated that ROSs play a pivotal role. A sustained hyperglycemic state causes an increased influx to the glucose metabolic pathway, resulting in the overactivity of the TCA cycle and the mitochondrial respiratory chain. Eventually, these pathways lead to the overproduction of ROSs and cellular damage. Although the oxidative metabolism of glucose, at least in neurons, is obligatory to normal brain function, it could act as a double-edged sword. The role of astroglia in the pathogenesis of diabetic encephalopathy and in terms of ROSs generation, however, has not been examined.

The major finding of the present study is that an elevated glucose concentration does not affect total glucose utilization, as assessed by monitoring $\left[{ }^{14} \mathrm{C}\right]$ deoxyglucose phosphorylation, or the oxidative metabolism of glucose, as assessed by monitoring $\left[{ }^{14} \mathrm{C}\right]$ lactate oxidation in neurons. In astroglia, on the other hand, oxidative metabolism (but not total glucose utilization) is suppressed by short-term or chronic increases in the environmental glucose concentration.

Energy production in astroglia is thought to be dependent on glycolysis, rather than oxidative metabolism. Recent findings, however, have revealed that oxidative metabolism in astrocytes in vivo is comparable to that in neurons both in vitro and in vivo [18]. We previously reported that the environmental glucose concentration is the major determinant of astroglial metabolism, in terms of glycolysis, rather than glucose oxidation [19]. A high glucose concentration reportedly elicits an increase in glucose utilization and lactate production in cultured astroglia $[34,35]$. However, the present results suggest that even acute hyperglycemia can elicit enhanced glycolysis in astroglia.

The suppression of oxidative metabolism of lactate or pyruvate (substrates for TCA cycle) was not caused by the decreased uptake by MCTs because the time courses of $\left[{ }^{14} \mathrm{C}\right]$ lactate uptake were similar in cultures with both glucose concentrations. Instead, the inactivation of PDH was thought to be the most likely mechanism, which was supported by the decreased oxidation of $\left[{ }^{14} \mathrm{C}\right]$ pyruvate. To further explore the effect of high glucose environments on TCA cycle activity, we examined the oxidation of acetate, an astrocyte-specific reporter molecule. Acetate normally exists in the plasma at a low concentration and is taken up only by astrocytes, where it then enters the TCA cycle without the involvement of PDH. This molecule, therefore, has been used to assess the oxidative metabolism of astrocytes both in vitro $[23,24]$ and in vivo [36-38]. The decreased production of ${ }^{14} \mathrm{CO}_{2}$ from $\left[{ }^{14} \mathrm{C}\right]$ acetate by astroglia induced by exposure to a high glucose concentration, either acutely or chronically, indicates that not only PDH activation, but also the activation of the TCA cycle overall is involved. The exact mechanism by which a high glucose concentration decreases oxidative glucose metabolism remains uncertain.

The decreased activity of TCA cycle irrespective of the unaltered total glucose utilization in astroglia indicates that glycolysis and lactate production could be enhanced in these cells under hyperglycemia. The glycolysis, especially its shunt pathway of glucose metabolism; pentose-phosphate pathway has been implicated to possess an important protective mechanism against ROS in concert with glutathione [39]. The fate of the increased lactate produced in vivo should be examined, since lactate can be used as an alternative energy source for neuronal oxidative phosphorylation. Conversely, [40] reported that astrocytic oxidative metabolism is essential to memory formation in young chicks. If persistent hyperglycemia suppresses oxidative metabolism in astroglia in vivo, it could affect intellectual function and might act as a direct causative mechanism of diabetic encephalopathy.

\section{CONCLUSION}

In conclusion, fluctuations in environmental glucose concentration do not alter glucose metabolism in neurons. In contrast, increasing the concentration of glucose, either acutely or chronically, suppresses oxidative metabolism in astroglia. These different responses of neurons and astroglia may shed new light on brain energy metabolism in diabetic patients with fluctuating plasma 
glucose concentrations.

\section{REFERENCES}

[1] Kannel, W.B. and McGee, D.L. (1979) Diabetes and cardiovascular risk factors: The Framingham study. Circulation, 59, 8-13.

[2] Biessels, G.J., Staekenborg, S., Brunner, E., Brayne, C. and Scheltens, P. (2006) Risk of dementia in diabetes mellitus: A systematic review. Lancet Neurology, 5, 64-74. doi:10.1016/S1474-4422(05)70284-2

[3] Brownlee, M. (2001) Biochemistry and molecular cell biology of diabetic complications. Nature, 414, 13-20. doi:10.1038/414813a

[4] Brownlee, M. (2005) The pathobiology of diabetic complications: A unifying mechanism. Diabetes, 54, 16151625. doi:10.2337/diabetes.54.6.1615

[5] Monnier, L., Mas, E., Ginet, C., Michel, F., Villon, L., Cristol, J.P. and Colette, C. (2006) Activation of oxidative stress by acute glucose fluctuations compared with sustained chronic hyperglycemia in patients with type 2 diabetes. Journal of the American Medical Association, 295, 1681-1687. doi:10.1001/jama.295.14.1681

[6] Ge, Q.M., Dong, Y., Zhang, H.M. and Su, Q. (2010) Effects of intermittent high glucose on oxidative stress in endothelial cells. Acta Diabetologica, 47, 97-103. doi:10.1007/s00592-009-0140-5

[7] McCall, A.L. (2004) Cerebral glucose metabolism in diabetes mellitus. European Journal of Pharmacology, 490, 147-158. doi:10.1016/j.ejphar.2004.02.052

[8] Abbatecola, A.M., Rizzo, M.R., Barbieri, M., Grella, R., Arciello, A., Laieta, M.T., Acampora, R., Passariello, N., Cacciapuoti, F. and Paolisso, G. (2006) Postprandial plasma glucose excursions and cognitive functioning in aged type 2 diabetics. Neurology, 67, 235-240.

doi:10.1212/01.wnl.0000224760.22802.e8

[9] Cox, D.J., Kovatchev, B.P., Gonder-Frederick, L.A., Summers, K.H., McCall, A., Grimm, KJ. and Clarke, W.L. (2005) Relationships between hyperglycemia and cognitive performance among adults with type 1 and type 2 diabetes. Diabetes Care, 28, 71-77. doi:10.2337/diacare.28.1.71

[10] McCall, A.L. (2005) Altered glycemia and brain-update and potential relevance to the aging brain. Neurobiology of Aging, 26S, S70-75.

doi:10.1016/j.neurobiolaging.2005.08.009

[11] Sommerfield, A.J., Deary, I.J. and Frier, B.M. (2004) Acute hyperglycemia alters mood state and impairs cognitive performance in people with type 2 diabetes. Diabetes Care, 27, 2335-2340.

doi:10.2337/diacare.27.10.2335

[12] Duckrow, R.B. and Bryan, R.M. Jr. (1987) Regional cerebral glucose utilization during hyperglycemia. Journal of Neurochemistry, 48, 989-993. doi:10.1111/j.1471-4159.1987.tb05614.x

[13] Orzi, F., Lucignani, G., Dow-Edwards, D., Namba, H., Nehlig, A., Patlak, C.S., Pettigrew, K., Schuier, F. and
Sokoloff, L. (1988) Local cerebral glucose utilization in controlled graded levels of hyperglycemia in the conscious rat. Journal of Cerebral Blood Flow and Metabolism, 8, 346-356. doi:10.1038/jcbfm. 1988.70

[14] Duelli, R., Maurer, M.H., Staudt, R., Heiland, S., Duembgen, L. and Kuschinsky, W. (2000) Increased cerebral glucose utilization and decreased glucose transporter Glut1 during chronic hyperglycemia in rat brain. Brain Research, 858, 338-347. doi:10.1016/S0006-8993(00)01942-9

[15] Blomqvist, G., Grill, V., Ingvar, M., Widén, L. and StoneElander, S. (1998) The effect of hyperglycaemia on regional cerebral glucose oxidation in humans studied with [1- $\left.{ }^{11} \mathrm{C}\right]-\mathrm{D}$-glucose. Acta Physiologica Scandinavica, 163, 403-415. doi:10.1046/j.1365-201X.1998.t01-1-00360.x

[16] Rosenkrantz, T.S., Knox, I., Zalneraitis, E.L., Raye, J.R., Porte, P.J., Cramer, R., Smoloski, R. and Phillipps, A.F. (1993) Cerebral metabolism and electrocortical activity in the chronically hyperglycemic fetal lamb. American Journal of Physiology, 265, R1262-R1269.

[17] Sieber, F.E., Brown, P.R., Wu, Y., Koehler, R.C. and Traystman, R.J. (1993) Cerebral blood flow and metabolism in dogs with chronic diabetes. Anesthesiology, 79, 1013-1021. doi:10.1097/00000542-199311000-00020

[18] Hertz, L., Peng, L. and Dienel, G.A. (2007) Energy metabolism in astrocytes: High rate of oxidative metabolism and spatiotemporal dependence on glycolysis/glycogennolysis. Journal of Cerebral Blood Flow and Metabolism, 27, 219-249. doi:10.1038/sj.jcbfm.9600343

[19] Abe, T., Takahashi, S. and Suzuki, N. (2006) Oxidative metabolism in cultured rat astroglia: Effects of reducing the glucose concentration in the culture medium and of D-aspartate or potassium stimulation. Journal of Cerebral Blood Flow and Metabolism, 26, 153-160. doi:10.1038/sj.jcbfm.9600175

[20] Takahashi, S., Driscoll, B.F., Law, M.J. and Sokoloff, L. (1995) Role of sodium and potassium ions in regulation of glucose metabolism in cultured astroglia. Proceedings of the National Academy of Sciences of the United States of America, 92, 4616-4620. doi:10.1073/pnas.92.10.4616

[21] Sokoloff, L., Reivich, M., Kennedy, C., Des Rosiers, M.H., Patlak, C.S., Pettigrew, K.D., Sakurada, O. and Shinohara, M. (1977) The $\left[{ }^{14} \mathrm{C}\right]$ deoxyglucose method for the measurement of local cerebral glucose utilization: Theory, procedure, and normal values in the conscious and anesthetized albino rat. Journal of Neurochemistry, 28, 897-916. doi:10.1111/j.1471-4159.1977.tb10649.x

[22] Smith, P.K., Krohn, R.I., Hermanson, G.T., Mallia, A.K.,Gartner, F.H., Provenzano, M.D., Fujimoto, E.K., Goeke, N.M., Olson, B.J. and Klenk, D.C. (1985) Measurement of protein using bicinchoninic acid. Analytical Biochemistry, 150, 76-85. doi:10.1016/0003-2697(85)90442-7

[23] Waniewski, R.A. and Martin, D.L. (1998) Preferential utilization of acetate by astrocytes is attributable to transport. Journal of Neuroscience, 18, 5225-5233.

[24] Waniewski R.A. and Martin, D.L. (2004) Astrocytes and synaptosomes transport and metabolize lactate and acetate differently. Neurochemical Research, 29, 209-217. 


\section{doi:10.1023/B:NERE.0000010450.21586.a6}

[25] Clarke, D.D. and Sokoloff, L. (1999) Circulation and energy metabolism of the brain. In: Siegel, G.J., Agranoff, B.W., Albers, R.W., Fisher, S.K. and Uhler, M.D., Eds., Basic Neurochemistry: Molecular, Cellular, and Medical Aspects, 6th Edition, Lippincott-Raven, New York, 637669.

[26] McKenna, M.C., Gruetter, R., Sonnewald, U., Waagepetersen, H.S. and Schousboe, A. (2006) Energy metabolism of the brain. In: Siegel, G.J., Albers, R.W., Brady, S.T. and Price, D.L. Eds., Basic Neurochemistry: Molecular, Cellular, and Medical Aspects, 7th Edition, Elsevier Academic Press, Burlington, 531-557.

[27] Madsen, P.L., Cruz, N.F., Sokoloff, L. and Dienel, G.A. (1999) Cerebral oxygen/glucose ratio is low during sensory stimulation and rises above normal during recovery: Excess glucose consumption during stimulation is not accounted for by lactate efflux from or accumulation in brain tissue. Journal of Cerebral Blood Flow and Metabolism, 19, 393-400. doi:10.1097/00004647-199904000-00005

[28] Chih, C.P. and Roberts, E.L. Jr. (2003) Energy substrates for neurons and during neural activity: A critical review of the astrocyte-neuron lactate shuttle hypothesis. Journal of Cerebral Blood Flow and Metabolism, 23, 1263-1281. doi:10.1097/01.WCB.0000081369.51727.6F

[29] Hertz, L. (2004) The astrocyte-neuron lactate shuttle: A challenge of a challenge. Journal of Cerebral blood Flow and Metabolism, 24, 1241-1248. doi:10.1097/00004647-200411000-00008

[30] Pellerin, L. and Magistretti, P.J. (2003) Food for thought: Challenging the dogmas. Journal of Cerebral Blood Flow and Metabolism, 23, 1282-1286. doi:10.1097/01.WCB.0000096064.12129.3D

[31] McNay, E.C. and Gold, P.E. (1999) Extracellular glucose concentrations in the rat hippocampus measured by zeronetflux: Effects of microdialysis flow rate, strain, and age. Journal of Neurochemistry, 72, 785-790. doi:10.1046/j.1471-4159.1999.720785.x

[32] Silver, I.A. and Erecińska, M. (1994) Extracellular glu- cose concentration in mammalian brain: Continuous monitoring of changes during increased neuronal activity and upon limitation in oxygen supply in normo-, hypo-, and hyperglycemic animals. Journal of Neuroscience, 14, 5068-5076.

[33] Jacob, R.J., Fan, X., Evans, M.L., Dziura, J. and Sherwin, R.S. (2002) Brain glucose levels are elevated in chronically hyperglycemic diabetic rats: No evidence for protective adaptation by the blood brain barrier. Metabolism, 51, 1522-1524. doi:10.1053/meta.2002.36347

[34] Schousboe, A., Westergaard, N., Waagepetersen, H.S., Larsson, O.M., Bakken, I.J. and Sonnewald, U. (1997) Trafficking between glia and neurons of TCA cycle intermediates and related metabolites. Glia, 21, 99-105. doi:10.1002/(SICI)1098-1136(199709)21:1<99::AID-GL IA11>3.0.CO;2-W

[35] Walz, W. and Mukerji, S. (1988) Lactate release from cultured astrocytes and neurons: A comparison. Glia, 1, 366-370. doi:10.1002/glia.440010603

[36] Cruz, N.F., Lasater, A., Zielke, H.R. and Dienel, G.A. (2005) Activation of astrocytes in brain of conscious rats during acoustic stimulation: Acetate utilization in working brain. Journal of Neurochemistry, 92, 934-947. doi:10.1111/j.1471-4159.2004.02935.x

[37] Dienel, G.A. and Cruz, N.F. (2006) Astrocyte activation in working brain: Energy supplied by minor substrate. Neurochemistry International, 48, 586-595. doi:10.1016/j.neuint.2006.01.004

[38] Hosoi, R., Okada, M., Hatazawa, J., Gee, A. and Inoue, O. (2004) Effect of astrocytic energy metabolism depressant on ${ }^{14} \mathrm{C}$-acetate uptake in intact rat brain. Journal of Cerebral Blood Flow and Metabolism. 24, 188-190. doi:10.1097/01.WCB.0000098606.42140.02

[39] Bolaños, J.P., Almeida, A. and Moncada, S. (2010) Glycolysis: A bioenergetic or a survival pathway? Trends in Biochemical Sciences, 35, 145-149. doi:10.1016/j.tibs.2009.10.006

[40] Gibbs, M.E., O’Dowd, B.S., Hertz, E. and Hertz, L. (2006) Astrocytic energy metabolism consolidates memory in young chicks. Neuroscience, 141, 9-13. 